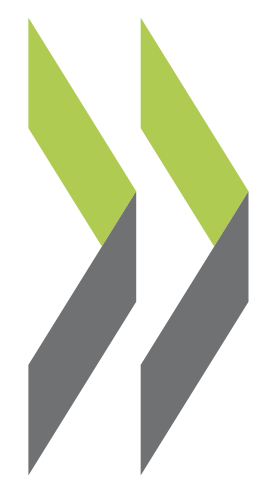

OECD Working Papers on Insurance and Private Pensions No. 18

\title{
Pension Fund Governance: Challenges and Potential Solutions
}




\title{
\ęC
}

PENSION FUND GOVERNANCE: CHALLENGES AND POTENTIAL SOLUTIONS

\author{
Fiona Stewart and Juan Yermo
}

June 2008

\section{OECD WORKING PAPER ON INSURANCE AND PRIVATE PENSIONS}

No. 18

Financial Affairs Division, Directorate for Financial and Enterprise Affairs Organisation for Economic Co-operation and Development

2 Rue André Pascal, Paris 75116, France

www.oecd.org/daf/fin/wp 


\begin{abstract}
RÉSUMÉ
Pension Fund Governance: Challenges and Potential Solutions

Good governance is increasingly recognized as an important aspect of an efficient private pension system, enhancing investment performance and benefit security. Yet, despite regulatory and industry initiatives, governance weaknesses persist across OECD and non-OECD countries. This paper highlights the main governance challenges faced by policymakers (particularly with trust-based pension systems), and draws on recent policy initiatives to propose possible solutions to strengthen governance arrangements.

The paper suggests that some of the more serious cases of governance failures could be solved through a more balanced representation of stakeholders in the governing body, higher levels of expertise (which may be achieved via training or the use of independent trustees) and the implementation of codes of conduct addressing conflicts of interest. The absence of governance arrangements for defined contribution style pension plans also needs to be addressed, potentially via management committees, increased fiduciary responsibility for relevant parties or via a strengthened role for pension supervisory authorities. Consolidation of the pension industry in some countries may also be required to achieve economies of scale and reduce costs, which in turn would allow pension funds to dedicate more resources to strengthening their internal governance.
\end{abstract}

JEL codes: G23, G32, J32

Keywords: governance, pension funds, conflicts of interest, fiduciary responsibility, trustee

******

\title{
La gouvernance des fonds de pension : défis à relever et solutions envisageables
}

La bonne gouvernance est de plus en plus considérée comme un aspect important de l'efficience des régimes de retraite privés, car elle accroît les performances des investissements et la sécurité des prestations. Malgré les initiatives adoptées sur le plan réglementaire et par les professionnels, la gouvernance reste néanmoins défaillante dans les pays membres et non membres de l'OCDE. Ce document met en relief les principaux défis qui se présentent aux responsables politiques dans ce domaine (notamment en cas de gestion sous mandat) et il s'appuie sur des mesures récentes pour proposer des solutions de nature à renforcer les dispositions relatives à la gouvernance.

Il semblerait que l'on puisse remédier à certaines des failles les plus préoccupantes des dispositifs en place en introduisant une représentation plus équilibrée des parties prenantes au sein de l'organe de direction, en relevant le niveau de compétence (par la formation ou en faisant appel à des administrateurs indépendants) et en adoptant des codes de conduite qui abordent la question des conflits d'intérêts. Il convient également de pallier l'absence de dispositions ayant trait à la gouvernance pour les plans de retraite à cotisations définies, par exemple en instaurant des comités de gestion ou en accroissant la responsabilité fiduciaire des parties concernées ou le rôle des autorités de contrôle du secteur des retraites. Dans certains pays, la concentration des intervenants sur ce marché peut aussi s'avérer nécessaire pour réaliser des économies d'échelle et réduire les coûts, ce qui permettrait aux fonds de pension de consacrer davantage de ressources à la consolidation de leur gouvernance interne.

Codes JEL: G23, G32, J32

Mots clés : gouvernance, fonds de pension, conflits d'intérêts, responsabilité fiduciaire, administrateur 


\section{Copyright OECD, 2008}

Applications for permission to reproduce or translate all, or part of, this material should be made to: Head of Publications Service, OECD, 2 rue André-Pascal, 75775 Paris Cédex 16, France. 


\title{
PENSION FUND GOVERNANCE: CHALLENGES AND POTENTIAL SOLUTIONS
}

\author{
by Fiona Stewart and Juan Yermo ${ }^{1}$
}

\section{Introduction}

The OECD has been discussing pension fund governance since 2000, with guidelines on topic approved by the Organisation's Working Party on Private Pensions in 2001 and released as an OECD Recommendation in 2005 (OECD(2005)). Since then, governance has only continued to rise in profile and has entered the policy agenda, with a few countries taking regulatory initiatives to strengthen the management of pension funds, often on the basis of the OECD guidelines.

This paper identifies some of main governance weaknesses that persist in pension fund systems around the OECD area and in selected non-OECD countries. The paper highlights problems in trust-based pension systems, but also touches on governance challenges that arise in other systems, in particular contract-based arrangements where the pension fund is governed directly by a financial institution. The document sets out some challenges faced by policymakers and possible solutions to strengthen pension fund governance. Though mostly applicable to trust-based pension systems, some of the suggestions are also be relevant for other pension arrangements.

Though not the focus of this paper, it should also be noted that particular concerns may arise for occupational plans for employees of government entities, such as have arisen for state and local governments in some countries, where such governments have independent authority regarding pension plans for their employees. In these cases, the laws of the countries involved may preclude the usual pension supervisory authorities from exercising control over such other governmental entities. In those cases, best practices may be for such governmental entities to supervise the governance of their own plans in a manner consistent with the principles underlying the guidelines for private pensions, with modifications as may be appropriate for the governmental nature of the employer.

Another area of concern not covered by this paper may be the provision of special pension benefits to select groups of management or highly compensated employees. In those cases, the need for these pension plans to receive the same protections or levels of governance, supervision or funding as occupational plans for other workers may not be warranted, and the supervisory authorities and laws may take that into account. As a general matter, however, the regulatory or tax regimes of the country should not encourage such arrangements over regulated, broad-based pension plans.

\footnotetext{
${ }^{1}$ Juan Yermo is principal administrator and Fiona Stewart an administrator in the Financial Affairs Division of the OECD's Directorate for Financial and Enterprise Affairs. The views expressed herein are those of the authors and do not necessarily reflect those of the OECD or the governments of its Member countries. The authors are solely responsible for any errors.
}

Contact information: Organisation for Economic Co-operation and Development, 2, rue André Pascal, Paris, F75775, France. E-mail: juan.yermo@oecd.org, fiona.stewart@oecd.org 
The paper is structured as follows. Section II presents the main arguments for strengthening pension fund governance, highlighting recent research which links good governance and investment performance. Section III identifies continuing weaknesses in pension fund governance in a variety of countries, based on recent surveys and independent studies, including some carried out by regulatory and supervisory authorities. Section IV describes the main policy initiatives launched in this area. The next two sections put forward various recommendations to improve the governance of occupational pension funds (Section V) and contract-based defined contribution arrangements (Section VI). The last Section concludes.

\section{Benefits from strengthening pension fund governance}

The governance of private pension plans and funds involves the managerial control of the organizations and how they are regulated, including the accountability of management and how they are supervised. The basic goal of pension fund governance regulation is to minimize the potential agency problems, or conflicts of interest, that can arise between the fund members and those responsible for the fund's management, and which can adversely affect the security of pension savings and promises. Good governance goes beyond this basic goal and aims at delivering high pension fund performance while keeping costs low for all stakeholders. Good governance can have many positive side effects such as creating trust amongst all stakeholders, reducing the need for prescriptive regulation, and facilitating supervision. Good pension fund governance can also be conducive to more effective corporate governance of the companies that they invest in, as well-managed pension funds are more likely to seek value for their investments via a more active shareholder policy. Good governance also needs to be 'risk-based'. For example, the more sophisticated the investment strategy the pension fund adopts, the stricter the governance oversight required; or the more complex the administrative arrangements of the plan, the tighter operational oversight needs to be.

In meeting these goals, pension fund governance is structured in different ways in different countries. All autonomous pension funds have a governing body or board, which is the group of persons (or in some cases a single person) responsible for the operation and oversight of the pension fund. The governing board is the ultimate decision-maker, having overall responsibility for strategic decisions such as setting the investment policy, choosing the investment manager(s) and other service providers, and reviewing the fund's performance. The pension fund's governing board is the equivalent of the board of directors of a corporation, which has the ultimate responsibility for protecting the shareholders' assets.

The governing body may be internal or external to the pension fund, it may have a single or dualboard structure and may delegate certain functions to professionals (see Box 1). These features of pension funds depend on the legal form of the fund and the regulation in place and are the starting point for understanding differences in the quality of pension fund governance across countries.

The central role played by the governing board in ensuring good governance and raising value for all stakeholders is increasingly being recognized. For example, in a recent study, Ambachtsheer et al. (2006) show how good governance and good performance are linked. Using pension funds based in Australia, New Zealand, Canada, the United States and Europe, their analysis is based on pension fund executives' own opinions of how well their governance is working as a proxy for good governance, with pension fund returns over a passive asset benchmark taken as a performance proxy. They conclude that "the 'poor-good' governance gap, as assessed by pension fund CEOs (or equivalents) themselves, has been 'worth' as much as $1-2 \%$ of additional return per annum" - and the authors think this is probably an underestimation. In a later article, Ambachtsheer et al. (2007) identify the main governance weaknesses as poor selection processes for members of the governing board, a lack of self-evaluation of board effectiveness, and weak oversight by the board. Other specific problems include lack of delegation clarity between board and management responsibilities, board micro-management, and non-competitive compensation policies in pension funds. 


\section{Box 1: Legal and governance structure of pension funds}

The structure of the governing body is determined by the legal form of the pension fund. There are two types of autonomous pension funds. There is an institutional type where the fund is an independent entity with legal personality and capacity and hence it has its own internal governing board. Examples of pension funds of the institutional type include pension foundations and associations as they exist in countries such as Denmark, Finland, Hungary, Italy, Japan, Norway, Poland, the Netherlands, and Switzerland, as well as corporations such as the "Pensionskassen" in Austria and Germany. In most of these countries pension funds have a single governing board, whose members are typically chosen by sponsoring employers and employees (or their representatives). In some countries, like Germany and the Netherlands, there is a dual-board structure. In Germany, there is a supervisory board which is responsible for selecting and monitoring the management board, which in turn is responsible for all strategic decisions.

By contrast a pension fund of the contractual type consists of a segregated pool of assets without legal personality and capacity that is governed by a separate entity, typically a financial institution such as a bank, insurance company or a pension fund management company. The governing body of a fund set up in the contractual form is usually the board of directors of the management entity, though in some countries (e.g. Spain) some key responsibilities are shared with a separate oversight committee ("comisión de control"). Other examples of pension funds set up in the contractual form include those in the Czech Republic, Mexico, Portugal, Slovakia, Turkey, and the open funds in Italy and Poland.

The trust, which is the legal form used by pension funds in countries with an Anglo-Saxon legal tradition, does not fit comfortably into either category. It has characteristics of both the institutional and the contractual type. Under the trust form it is the trustees who legally own (have the legal title to) the pension fund assets. Trustees must administer the trust assets in the sole interest of the plan participants, who are the beneficiaries from the investment of those assets according to the trust deed. While this feature of trusts is similar to that of foundations, the trustees are not legally part of the trust. Indeed, a trustee may be of the corporate type (as in sometimes the case in Australia and Ireland) which makes the pension fund resemble a contractual arrangement.

The United States has an additional feature as the governing body may be the plan sponsor, the trustee, or/and some third party. ERISA requires single company pension plans to have one or more "named" fiduciaries who have authority to control and manage the pension plan, including its investments. The sponsoring employer and the trustee are always named fiduciaries but it is possible for the trustee to be devoid of any major fiduciary responsibility (directed trustee), following instead another named fiduciary (e.g. a plan committee). In addition, asset managers, financial advisors and other persons and entities that exercise some discretion over the fund's assets are considered "functional" fiduciaries, all of whom have some legal responsibility for the pension fund.

In a study of a sample of large pension funds (over US\$5bn in assets) from 6 different countries dispersed across North America, Europe and Asia-Pacific, Clark and Urwin (2007) also conclude that their superior performance is linked to strong governance. Their study identified various areas where the funds analysed excelled, such as clarity of mission and effective risk management and performance monitoring. The presence of a CIO was deemed as critical to ensure these successful outcomes. The report includes both governance capacity as well as investment strategy in the risk profile of the fund, and recommends linking the investment strategy of the fund to the governance capability of the board. For example, boards should first decide whether they are capable of monitoring alternative investments effectively before debating whether to include such instruments in their investment strategy.

A study by consulting firm Mercer on pension funds in the United Kingdom partly attribute improvements in pension fund deficit levels (which improved from GBP-40bn to GBP-2bn in 2007) to strengthening pension fund governance ${ }^{2}$. They postulate that the basic training of trustees on how to

\footnotetext{
${ }^{2}$ http://uk.mercer.com/pressrelease/details.jhtml/dynamic/idContent/1292675
} 
oversee fund managers has led to better performance through more sophisticated money management and risk management. In turn the improvement in trustee performance is attributed to the stricter requirements laid down in the 2004 Pensions Act.

Good governance can also bring indirect benefits to pension funds. It can spare them the costs of overregulation and it can facilitate supervision by the authorities. In particular, as pension fund supervisors adopt a risk-based approach to supervision, pension fund governance has become central to deciding whether or not an institution should be closely monitored. The stronger the governance of the fund, the better risks (such as operational risk, investment risk) will be managed and controlled. The supervisory approach is increasingly dictated by their assessment of a pension fund's risk profile, with funds judged to pose less risk likely to receive a lighter supervisory touch. This could mean that more of the day to day 'governance' or 'supervision' of the fund is left to the governing board itself.

Good pension fund governance can also have positive collateral effects on economy-wide efficiency, strengthening the fund's role as effective shareholders - a role which is becoming more central given the increasing size of pension fund assets globally. Better corporate governance can also enhance investment returns. The link between pension fund governance and corporate governance has been recognised by, among others, Clapman et al. (2007) from the perspective of the United States.

Pension fund trustees in some countries like the United Kingdom are also becoming involved in transactions involving their corporate sponsor. For example, the trustees of the pension fund of two UK high street retailers, Boots and Sainsburys, entered negotiations surrounding highly leveraged bids by private equity firms in order to protect benefit security. Specifically, they demanded increased funding from the potential acquirers to cover pension liabilities, as they deemed that the level of security in meeting pension promises would be lower with the new plan sponsor. The Pensions Regulator has also issued guidance to trustees on how to react to corporate transactions that result in significant reductions in the security of the plan sponsor's covenant. ${ }^{3}$

\section{Continuing challenges in pension fund governance}

However, despite increased understanding of the importance of good governance for pension funds, problems still remain. In recent years, pension fund governance issues have hit the headlines. Some of the more serious cases of governance failures include issues surrounding the Swissfirst affair involving Pensionskassen in Switzerland (concerning problems with pension fund managers trading the same shares as the pension funds which employ them). These problems have prompted a governance review, whilst the ASIP (the schemes' representative body) is pushing for existing codes of practice to be adopted more widely and the government is said to be contemplating legislation.

In Hungary, where pension funds are established as not-for profit institutions, there is evidence that the governing body is generally ineffective in looking after the best interest of members. Most funds are established by financial institutions that find it easy to promote their candidates to the fund's supervisory board.

Some pension funds in the United States have also been the subject of governance problems, with directors of TIAA-CREF resigning in 2004 over conflict of interest issues, and problems also being experienced at some public pension funds (in San Diego, New Jersey and New York - referenced in Clapman et al. (2007)) $)^{4}$. Meanwhile issues in Greece have surrounded the pricing of public pension fund

\footnotetext{
${ }^{3}$ Financial Times, 30 July 2007, 'Wise to have a plan at the ready should a buyer come knocking'

${ }^{4}$ In the U.S., under principles of federalism, state and local government pension funds for the employees of state and local governments are exempted from many of the federal pension laws and are instead regulated by the state or
} 
bond purchases, with the government reacting by issuing new rules regarding the selection of board members ${ }^{5}$.

Various studies and surveys have also identified general governance problems that affect broadly and deeply the pension fund industry. Ambachtsheer et al (2006) is part of a continuing investigation into pension fund governance which covers funds in Australia, Canada, New Zealand, the United Kingdom, and the United States, among other countries. The study found that governance practices were improving but that there were still many lingering problems.

A survey by Mercer (2006) of the governance of global retirement plans offered by multinational corporations found that sponsoring employers are very concerned about the lack of governance of their benefit plans in the different countries in which they operate. A lack of resources (including skills) and weak local engagement were found to be the most common challenges multinational corporations had in meeting their global pensions governance goals.

The International Organisation of Pension Supervisors (IOPS) recently surveyed its members to ascertain which governance issues they find the most challenging ${ }^{6}$. Initial results suggest that pension fund supervisors are particularly concerned with transparency and the disclosure of information to pension fund members, the competency and expertise of the governing body and internal controls. Incidents leading supervisors to increase their focus on governance include the rising complexity of the pension fund industry and rising demands on the competence of the governing body. Adjusting legislative requirements and increasing supervisor oversight were the most usual responses.

Country specific surveys include a report by Marr et al (2006) highlighting administrative problems in governance practices in the United Kingdom, claiming that 1 in 3 pension funds still have administrative problems (from using the wrong index level, or wrong salary to calculate pension benefits to allocating spouse benefits to the wrong account).

The UK Pensions Regulator's (TPR) survey of UK pension fund governance (Pensions Regulator (2007b)) found improvements in governance practices. For example, more trustees were undertaking training, scheme confidence in managing conflicts of interest had risen significantly and more trustees were examining the financial state of the plan sponsor. Yet despite these improvements it is clear there remains a need to improve the level of training provided, particularly to further reduce the proportion of schemes that do not undertake training. The disparity between DB and DC was of particular concern, with a higher percentage of trustees of DB schemes undertaking training than trustees overseeing DC schemes. The survey also highlighted other challenges in areas such as risk management, internal controls and managing scheme administration. Governance of pension schemes has been a legislative and regulatory priority for many years and The Pensions Regulator's Medium Term Strategy (2008-2009) has identified improving governance of work-based pension schemes as a key priority.

In their governance discussion paper (Pensions Regulator 2007a) TPR also saw conflicts of interest as one of the major governance challenges. The duty of the trustee to act in the best interests of beneficiaries

local government entities themselves. A recent report by the Pew Center on the States (2007) indicates that pension plans for employees of state and local governments in the United States are approximately $85 \%$ funded, though funding levels vary widely from plan to plan.

${ }^{5}$ IPE $16^{\text {th }}$ April 2007, 'Greece sets new pension governance rules' http://www.ipe.com/news/Greece_sets_new_pension_governance_rules_21831.php

\footnotetext{
${ }^{6}$ Results taken from IOPS (2008).
} 
is imposed by the principles of trust law. Accordingly, all decisions made by trustees in regards to these areas should be unfettered and made first and foremost in the best interests of beneficiaries. Whilst conflicts are inevitable in many cases, the pertinent issue is that they are appropriately managed. The governance survey found the most common conflict to be the dual role held by a trustee as a director or finance director of the sponsoring company. The 2007 survey showed that since 2006 confidence in managing conflicts of interest has increased significantly but managing such conflicts will continue to be a challenge.

The Pensions Ombudsman in the United Kingdom, in the 2005 Annual Report, likewise comments that while the administration of pension schemes in the United Kingdom is improving ${ }^{7}$ work needs to be done to ensure that independent trustees are effectively regulated. The Ombudsman is concerned that those providing a professional service currently do not have the liability to provide redress if mistakes are made.

Clark $(2006,2007)$ has also surveyed the ability of pension fund trustees in the UK. In the 2006 paper looking at trustee competence (Clark (2006)), trustees' ability in solving problems relevant to their investment responsibilities is examined. The results show that trustees are more cautious with other peoples' money than their own, which may be an impact of the predominance of the prudent person rule in UK common law. The fact that trustees are not professionals has also led to concerns that trustees may lack the understanding to judge advice they receive from experts. Clark (2007) notes a growing tension between representation and expertise in several fields, using UK pension fund governance and the USA mutual fund industries as examples. The evidence suggests that very few trustees have the competence and consistency of judgment to challenge the experts who are responsible for executing complex financial decisions. There is a clear association between trustee boards' understanding across key topics and their confidence levels in managing their schemes. The importance of guidance is evident, and The Pensions Regulator continues to use education as the means to change behavior across schemes. Trustees are required to comply with 'trustee knowledge and understanding' (TKU) requirements and develop further their knowledge to ensure they are confident in dealing with the more complex aspects of running their schemes.

Cocco and Volpin (2005), looking at DB plans in the UK, found that pension plans of indebted companies with more 'insiders' (i.e. also executive directors of the sponsoring company) on the trustee board invested more in equities, contributed less to the pension fund and had a higher dividend payout ratio. The conclusion drawn is that when finances get tough, conflicts of interest may arise and impartial trustees are needed on the board to make governance work. However, other explanations could be found such as trustees who are also directors of the sponsoring company potentially having greater investment knowledge which would allow them to maximize returns and therefore lower funding demands for the sponsor.

Two recent studies have specifically focused on the issue of the differences between the levels of DB and DC governance in the United Kingdom. A recent NAPF survey concluded that trustees were not doing enough to explain that there may well be better ways for members to deploy their funds (NAPF (2007b)). A Cass Business School report on "reluctant investors" (Byrne, Harrison, Blake (2007)) points out that, with the exception of senior executives, it is unusual for employers to pay for face-to-face regulated investment advice (due to cost). In its DC consultation work (Pensions Regulator (2007c)) The Pensions Regulator has concluded that two of the areas where there are opportunities for improvements are with member understanding and member choices, and the Regulator has stated that it will issue guidance for trustees with the aim of raising standards in those areas. The guidance will be targeted primarily at trustees, encouraging them to take a more pro-active role in member education.

\footnotetext{
${ }^{7}$ http://www.pensions-ombudsman.org.uk/news/index.asp
} 
In Ireland, the Pensions Board produced a review in 2006 of the trustee structure of governance (Pensions Board (2006)). The Irish report identified some weaknesses such as the small size of some schemes, wide variation in awareness and understanding of trustee responsibilities and conflicts of interest among trustees, particularly among employer nominated trustees of defined benefit plans. In addition, the Pension Board's review found evidence that ongoing, quality trustee training was the exception rather than the rule.

Governance problems also affect countries that have mainly contract-based private pension arrangements, where pension funds take a contractual form. In most Central and European countries like Poland and Slovak Republic and Latin American countries, such as Mexico, mandatory pension funds are managed by financial institutions that are faced with potential conflicts of interest. Given the low level of education of the population and the generally low interest in pension matters, there is an incentive for pension fund managing companies to engage in costly marketing campaigns to attract membership. Such campaigns often provide little benefit in terms of improved investment performance but lead to high administration costs and fees paid by the plan members.

Governance reviews have also been carried out in some non-OECD countries with occupational pension systems. For example, Dias (2006) argues that in Brazil, sponsoring employers tend to dominate decision-making at pension funds, even though nominally the main decision-making body is the so-called deliberative council (a kind of supervisory board). There were also some instances in which the one-third member representation of members in the deliberative council were not being met.

Rusconi (2008) has reviewed pension fund governance in South Africa and has identified major knowledge gaps in trustee boards, weak board discipline, and conflicts of interest among consultants and asset managers that are going unaddressed, leading to a prevalence of active over passive management and higher fees than would otherwise be the case. Such conflicts reach even training programmes for trustees as these are mostly delivered or financed by asset managers and consulting firms.

In summary, several main challenges relating to pension fund governance remain, primarily in trustbased and contract-based pension systems. First, trustees and fiduciaries generally lack suitable knowledge, experience or training, which additionally hinders them from being able to understand and challenge advice they receive from outside experts. Second, conflicts of interest still remain, both within boards and in relation to independent, commercial trustees. Finally, the problem of how to ensure that suitable governance mechanisms are in place for contract-based DC schemes has also yet to be solved.

\section{Recent policy and industry initiatives}

Policymakers in many OECD countries have recently stepped up efforts to address perceived weaknesses in the governance of pension funds. In some cases, regulators have even enshrined governance best practices similar to the OECD guidelines in the country's pensions legislation. Industry associations have also taken the initiative in some countries and are driving a reform in governance practices, encouraging funds to improve their self-regulation through better governance practices.

Recently, some countries have introduced governance regulations, sometimes taking the form of recommendations rather than strict requirements. The principles of good governance that have been developed follow broadly the OECD guidelines. These initiatives include the following:

- In Australia, the licensing of trustees was made mandatory in July 2006, a first among AngloSaxon countries. The assessment of "fit-and-proper" requirements is an integral part of the licensing process. 
- In Belgium, the CBFA released in May 2007 Circular CPP-2007-2-LIRP/WIBP on the governance of IORPs (the European Union term for pension funds).

- In Brazil, the regulator issued resolution \#13 in January 2005, covering a set of guiding principles and regulations on pension fund governance.

- In Canada, CAPSA introduced a code of pension plan governance in 2004.

- In Denmark the Pensions Market Council's report on good governance in labour market pension funds contains a set of principles for the responsibilities of boards, their tasks, composition and working methods. The Danish FSA has also released detailed supervision with a description of board responsibilities.

- In Greece, the government issued new rules concerning the selection of board members of public pension funds.

- In Ireland, the Pensions Board is considering making the training of trustees compulsory.

- In the Netherlands, the DNB has announced that from January 2008 it will start assessing the Principles of Pension Fund Governance laid down in the Pension Act (and which were developed by the STAR labour foundation).

- In Portugal, the insurance and pension fund supervisory authority (ISP) issued new regulation ('Norma Regulamentar no. 7/2007-R, de 17 de Maio', under Decree Law nr. 12/2006, of January 20th) on the governance structure of pension funds, addressing issues including the Pensions Ombudsman, Pension Fund Auditor, Appointed Actuary and Monitoring Committee of the Pension Scheme ('Comissão de Acompanhamento do Plano de Pensões').

- In South Africa, the FSB released in June 2007 Circular PF No.130 on "good governance of retirement funds".

- In Switzerland, the Federal Agency for Social Insurance is considering the introduction of governance regulations ${ }^{8}$.

- In the United Kingdom, the 2004 Pensions Act requires trustees to have knowledge and understanding of the law relating to pensions and trusts, and other matters, and to be conversant with the scheme trust deed and rules and other material. The Pensions Regulator is responsible for ensuring that this requirement is met, and developed a framework for trustee knowledge and understanding (the TKU regime). ${ }^{9}$

\footnotetext{
${ }^{8}$ This would strengthen the current 'self-regulation' approach which may not be working sufficiently rigorously, with one survey suggesting that less than half Swiss pension funds have adopted the industry-wide code. Reasons given include being subject to strict regulations elsewhere and costs. See 'Moving Governance up the Agenda' IPE December 2007

${ }^{9}$ The Pensions Regulator has recently published the final module of its trustee toolkit, 'running your scheme', which focuses on governance. It has also produced a code of practice and scope guidance which interprets the requirement for trustees to have knowledge and understanding of the law relating to pensions and trusts. Earlier, the Myners Report on institutional investment placed a high level of importance on the need for trustees to be "familiar with issues' when considering investment decisions. The report, with its number of investment principles, has become a voluntary code.
} 
- The IORP Directive (2003/41/EC) of the European Commission also contains some requirements relating to the good governance of pension funds in the European Union ${ }^{10}$.

Pension fund industry associations have also been active in some countries in developing standards on pension fund governance:

- In Canada, the Common Front for Retirement Security was set up by 14 groups (including the CARP -Canada's Association for the Fifty Plus- Investor Protection Association, Royal Canadian Legion and several prominent seniors/pensioners groups etc.) representing 2 million people. The organisation's goal is to campaign for better governance of pensions, investments and retirement savings ${ }^{11}$. This initiative follows on an earlier one by the Pension Investment Association of Canada (PIAC) in 1999 establishing a set of recommendations on pension plan governance.

- In the United Kingdom, the National Association of Pension Funds (NAPF) launched a review of the governance arrangements of pension schemes. A discussion paper ${ }^{12}$ was prepared to promote a debate on the important issue of pension scheme governance to effectively protect the interests of working people. A draft code on governance was submitted for public consultation, which covers among other issues, the obligations of the governing body, risk management, managing conflicts of interest, and internal controls.

- In the United States, best practice principles for the governance of US pension, endowment and charitable funds were released in 2007 by the Stanford Institutional Investors' Forum (SIIF) Committee on Fund Governance (see Clapman et al. (2007)).

\section{Strengthening governance in occupational pension funds}

Many of the problems in pension fund governance emerge from weaknesses in the governing board. These can take several forms:

- The responsibilities of board members are not clearly defined: the board may lack a clear mission statement and may engage in operational duties which should be left to internal management staff or external service providers.

\footnotetext{
${ }^{10}$ For example, Article 9 states that these institutions effectively run by persons of good repute who must themselves have appropriate professional qualifications and experience or employ advisers with appropriate professional qualifications and experience; should have properly constituted rules regarding the functioning of any pension scheme operated by the institution have been implemented and members have been adequately informed of these rules; requires that all technical provisions are computed and certified by an actuary or, if not by an actuary, by another specialist in this field; and that the members are sufficiently informed of the conditions of the pension scheme, in particular concerning:

(i) the rights and obligations of the parties involved in the pension scheme;

(ii) the financial, technical and other risks associated with the pension scheme;

(iii) the nature and distribution of those risks.

In addition, Article 12 requires a written statement of investment-policy principles to be produced at least every 3 years (including as a minimum investment risk measurement methods, the risk-management processes implemented and the strategic asset allocation). See http://europa.eu.int/eurlex/lex/LexUriServ/LexUriServ.do?uri=CELEX:32003L0041:EN:HTML

${ }^{11}$ http://www.globeinvestor.com/servlet/story/CNW.20070711.C5666/GIStory

${ }^{12}$ National Association of Pension Funds (2005).
} 
- Selection on the basis of representatives of stakeholders: in many countries board members are often selected on the basis of their status in a trade union or employer, rather than their specific knowledge or experience on pension issues.

- Lack of self-assessment, including training needs: governing boards rarely subject themselves to a thorough self-assessment review, to evaluate the extent to which their objectives are met and propose improvements to their decision-making methods.

- Conflicts of interest are not effectively identified and tackled: in many countries it is not required to have a code of conduct to manage conflicts of interest within pension funds.

Compounding these challenges is the problem of scale, which can be a major handicap for good governance. Small pension funds are unable to reap economies of scale and hence have high costs of administration. For example, a survey of pension funds in Ireland showed that management costs represented $3.64 \%$ of assets under management (AUM) in schemes with less than 50 members, but only $0.32 \%$ in schemes with more than 500 members (see Pensions Board (2006)). In the Netherlands, management costs for funds with less than 100 members were $0.59 \%$ of AUM and $0.07 \%$ in funds with more than $1 \mathrm{~m}$ members. Similarly, costs were $1.23 \%$ of AUM in funds with less than 10 million euro in assets and $0.1 \%$ in funds with more than 10 billion euro (see Bikker and de Dreu (2006)).

Small funds are also likely to be backed by small employers, which may lack workers and even executives with relevant skills and experience to sit in the governing board. While training may help mitigate this weakness, it is unlikely that a small fund will be able to achieve a comparable level of performance, even before fees, than a large fund as the latter can rely on a broad set of skills in its sponsor's workforce, including various finance specialists. Small funds are also less likely to develop governance structures and processes that are consistent with the fund's size and mission. They may be more exposed to conflicts of interest and be at the mercy of consultants and external advisors who may lead them to make risky investments that they may not fully understand.

The use of 'Master Trusts', as is the case in Australia, the United Kingdom, and other Anglo-Saxon countries, may be one way around the governance challenges facing smaller pension funds. Under such arrangements, the fund is directly under the control of a specialist institution, such as an insurance company or benefit consulting firm. But such solutions come with their own challenges (notably how to control conflicts of interest). An equivalent option being considered in defined benefit arrangements is "fiduciary management" of the pension fund, whereby a commercial provider takes care of not just the operational but also some key decisions of the fund, such as strategic asset allocation and external manager selection and monitoring. It is unclear whether commercial providers can manage the conflicts of interest inherent to such activities. One option to better align the incentives of the fiduciary manager would be for the pension fund to take an equity stake in the manager, as was recently done by a medium-sized pension fund in the Netherlands. However, such stakes need to be sufficiently large in order to have an impact on the manager's incentives. Small funds, given their size and diversifications goals, may gain little by investing in their fiduciary managers.

Other solutions that have been quite effective in some countries involve multi-employer arrangements, such as the industry-wide pension funds that exist in countries like Australia, Denmark and the Netherlands. Such pension funds were originally established via collective bargaining arrangements at the industry level, but in the case of Australia are now also open to companies and workers outside their industry. 


\section{V.1. Defining the board's responsibilities}

The main duties of the governing board of an occupational pension plan should normally be enshrined in the relevant legislation. The pension plan or fund statutes will include these duties and make them more specific to the fund's situation. The central responsibilities of any pension fund board should be to set out a clear mission for the fund, including specific measureable objectives (e.g. investment performance, funding levels, etc), to define a strategy for meeting those objectives (e.g. select a broad asset allocation, choose between internal and external management, etc), and to monitor the fund's success (and its staff's and external managers') in achieving those objectives. The board also needs to consider suitable governance structures for implementing its long-term strategy and consider for example whether a Chief Investment Officer should be appointed and how this person will be monitored and remunerated. Equally, in most instances, the board should be assisted by an investment committee and there may be a need to set up other committees to cover issues such as actuarial studies and audits.

In practice, however, the duties of the governing board are sometimes broadly defined, and may be interpreted as to include day-to-day decisions that are best left to operational staff, whether internal or external (see Ambachtsheer et al (2007)). The opposite problem is also present in some countries, where the board's responsibilities do not go as far as they should. For example, the board may not review the performance of the fund's senior staff and external service providers with sufficient regularity. In Spain, a diffusion of responsibilities arises because the role of "control commissions" overlaps with that of the pension fund management company. For example, the "control commission" - made up of representative of employers and employees - is expected to prepare the investment principles of the fund jointly with the pension fund managing company. As a result of this requirement, management companies play a key role in the design of the investment policies - an important task which should normally be solely in the hands of the governing board (though, when necessary, after heeding the advice of experts).

The governance system in place in Germany, with its two-tier board system, is an example of a country where clear responsibilities are applied to pension fund board members. As joint-stock companies or mutual insurance/pension fund associations, Pensionskassen and Pensionsfonds must follow the two-tier board structure required by law for listed corporations. The duties of both the managing and supervisory boards are laid down in relevant legal provisions. Key duties - including the choice of investment policy, the selection and monitoring of the fund's key executive staff and external service providers, and the monitoring of the fund's performance have to be fulfilled by the managing board and not the supervisory board. The supervisory board appoints, supervises and advises the management board. The positions and duties of the different board members must also be clearly indicated. In practice the dual board system, also established in other continental European countries, and the internationally widespread system of management by a single management body (Board of Directors) converge because of the intensive interaction of the managing and the supervisory boards.

The following examples, drawn from international good practice, are suggestions for overcoming the governance shortcomings mentioned above:

- Ensure relevant legal provisions clearly defines the main duties of pension fund boards, focusing on key, strategic decisions and functions such as the choice of investment policy, the selection and monitoring of the fund's key executive staff and external service providers, and the monitoring of the fund's performance. 
- Require that the documents governing the pension plan and/or pension entity clearly define the role and responsibilities of the governing board, calling on the pension fund board to set out clear, measurable objectives ${ }^{13}$

- Encourage members of the governing board to restate annually that they are aware of their governance obligations and other key documents relating to the fund.

- Subject to the governance resources available to the fund, consider the use of subcommittees (such as an investment committee) to ensure that key topics receive the required level of consideration and the appointment of a top executive responsible for investment management (e.g. a Chief Investment Officer).

\section{V.2 Composition of pension fund boards}

In nearly all OECD countries, the members of occupational pension fund governing boards must be selected by sponsoring employers and employees, often in equal numbers (see Table 1). The main exceptions are Canada, Ireland, Mexico, and the United States, where there is no requirement for employee or member representation in single employer plans. US legislation, however, calls for paritarian representation for multi-employer plans. In some other countries like Austria, and the United Kingdom, member representation is required but not necessarily in equal numbers to sponsor representation. In Japan, contractual-type pension funds do not need to have equal representation of employers and employees, while foundation-type pension funds do. The three non-OECD countries listed in Table 1 (Brazil, Israel, and South Africa) also display a diverse approach to member-representation, with only one (South Africa) requiring equal representation.

Table 1. Representation in occupational pension fund governing boards

\begin{tabular}{|l|l|}
\hline Australia & $\begin{array}{l}\text { Non-public offer funds (company and industry-wide funds) must have an equal number of } \\
\text { employer representatives and member representatives on the board of directors of the } \\
\text { corporate trustee or in the board of trustees. }\end{array}$ \\
\hline Austria & $\begin{array}{l}\text { The board of supervisors of the pension fund may have two seats fewer for employee } \\
\text { representatives than for the sponsoring employer or other shareholders of the pension fund. }\end{array}$ \\
\hline Belgium & $\begin{array}{l}\text { The board of directors of a pension fund must have equal representation of employers and } \\
\text { employees. }\end{array}$ \\
\hline Brazil & $\begin{array}{l}\text { At least one third of the supervisory board and the audit committee must be composed of } \\
\text { worker representatives. }\end{array}$ \\
\hline Canada & $\begin{array}{l}\text { There are no requirements for single employer plans. Multi-employer plans established } \\
\text { pursuant to a collective agreement are governed by a board of trustees composed in } \\
\text { accordance with the plan or collective agreement (typically equal representation). }\end{array}$ \\
\hline Germany & $\begin{array}{l}\text { Supervisory Board: employee representation depends on the number of employees in the } \\
\text { pension fund, with a maximum of equal representation. } \\
\text { The managing board is appointed by the supervisory board. }\end{array}$ \\
\hline Hungary & Mandatory pension funds must have member representatives in their board of directors. \\
\hline
\end{tabular}

${ }^{13}$ See OECD Guidelines on pension fund governance and asset management (OECD (2005) and OECD (2006), respectively).

${ }^{14}$ In Germany the supervisory board is elected by the general assembly or, if stated in the statutes, the board can be appointed by the general assembly directly. The board therefore reflects the proportions of the general assembly. According to the size of the joint-stock company or mutual association representation of employees may be required. There are no legal requirements for the representation of plan members or beneficiaries in the administration of pension plans. It is possible for the sponsor to be represented in the supervisory board, subject to legal conditions. 


\begin{tabular}{|l|l|}
\hline Iceland & The board of the pension fund must have equal representation of employers and employees. \\
\hline Ireland & No requirement for employee representation. \\
\hline Israel & No requirement for employee representation. \\
\hline Italy & $\begin{array}{l}\text { The general assembly and the board of directors must each have equal representation of } \\
\text { employers and employees. }\end{array}$ \\
\hline Japan & $\begin{array}{l}\text { The Board of Representatives of Employee Pension Funds must have equal representation } \\
\text { of employers and employees. }\end{array}$ \\
\hline Mexico & No requirement. \\
\hline Netherlands & The board of the pension fund must have equal representation of employers and employees. \\
\hline Norway & $\begin{array}{l}\text { The board of the pension fund must have at least as many employee as employer } \\
\text { representatives. }\end{array}$ \\
\hline Poland & $\begin{array}{l}\text { Not less than half of the members of the supervisory board of the occupational pension } \\
\text { society should be nominated by the members of the fund. }\end{array}$ \\
\hline Spain & $\begin{array}{l}\text { The majority of the control commission must be selected by plan members and } \\
\text { beneficiaries. No requirement for member representation in the board of pension fund } \\
\text { management companies. }\end{array}$ \\
\hline South Africa & At least half of trustees must be elected by plan members. \\
\hline Sweden & The board of the foundation must have equal representation of employers and employees. \\
\hline Switzerland & $\begin{array}{l}\text { The supreme council of a pension fund must have equal representation of employers and } \\
\text { employees. }\end{array}$ \\
\hline United Kingdom & At least one third of trustees must be member-nominated. \\
\hline United States & $\begin{array}{l}\text { No requirements for single-employer funds. Multi-employer (Taft-Hartley) funds must } \\
\text { have equal representation of employers and employees. }\end{array}$ \\
\hline
\end{tabular}

Employee or member representation can ensure a better alignment of the interest of the governing board with those of the fund's beneficiaries (see also section V.4 on handling conflicts of interest). They can also act as a conduit for delivering information to plan members, strengthening the accountability of the governing board. For instance, the benefits of member representation were recognised in a recent report by the Irish Pensions Board (2006). The report highlighted that those funds that did not have member representatives on the board welcomed them. "In fact, several employer-nominated interviewees suggested that the presence of member trustees provided protection against the emergence of such conflicts." Views on the skill levels of member trustees varied, most seeing member trustees as often offering valuable perspectives beyond that which is provided by company management (though they may need help, particularly with investment issues): "It was evident from the research that the principle of member trustees had been accepted by all trustees interviewed, with many outlining the positive contribution that such trustees can bring to the trustee board. Of those schemes without member trustees, all of those respondents stated that the member trustees would be welcomed to the trustee board if there were sufficient interest amongst scheme members." "Member trustees play an active and unique role in pension scheme governance...member trustees particularly act as intermediaries in the interface between service provider and employee, channelling information to scheme members in a role which has the flexible capacity to serve in members' best interests in varied and changing circumstances."

At the same time, there are questions over the contribution of member representatives to decisionmaking on some complex matter relating to the pension fund orientation. For example, member representatives may not have the necessary knowledge and understanding of investment matters and may not feel comfortable challenging investment advisors or the plan sponsor's senior executives sitting on the board. There is also concern on the part of employers that, because member representatives do not directly bear plan costs, they may have an incentive to add special benefits to DB plans without regard to costs or to avoid underfunding without a counterbalancing incentive to minimize costs. This may include the distortion of investments in an overly conservative manner unnecessarily driving up employer contributions. Another concern is that plans heavily influenced by the interests of member representatives tend to have features that favour the specific categories into which such representatives fall, even though it may not be in the interests of plan members broadly. 


\section{V.3 Suitability (“fit and proper") criteria}

Most countries have introduced criteria that disqualify certain individuals from pension fund boards. The specific criteria vary across countries but generally include insolvency under administration, criminal records and other evidence of "improper" behaviour. For example, in the United States, conviction of criminal acts and prior breaches of fiduciary duty may disqualify one from service as a fiduciary.

On the other hand, few countries require pension fund board members to have specific qualifications and professional experience that would allow them to carry their duties more effectively (e.g. Austria, Finland, Germany, Poland). In addition, a few OECD countries (e.g. Australia, Belgium, Denmark, Hungary, Portugal, and the Netherlands) have introduced general suitability ("fitness") requirements for the members of the governing board beyond the basic disqualifying conditions (such as criminal records or insolvency) that exist in most countries. Some countries (e.g. France, Japan) have no legal fit and proper requirements for board members.

\section{Table 2. Fit and Proper Requirements for Governing Board Members}

\begin{tabular}{|c|c|}
\hline Australia & $\begin{array}{l}\text { The standards for fitness and propriety of the governing body are prescribed within the legislative } \\
\text { framework and additional guidance on this requirement is provided by APRA. This standard } \\
\text { prescribes that the governing body possesses attributes which include reference to character, } \\
\text { competence, diligence, experience, honesty, integrity, judgment as well as educational and } \\
\text { technical qualifications, knowledge and skills. } \\
\text { The propriety standard must be met on an individual basis, whilst the fitness standard is required to } \\
\text { be met on a collective basis such that the governing body must have the collective skills, } \\
\text { qualifications and experiences to fulfill its role. Guidance is provided on what APRA considers } \\
\text { minimum standards for fitness of individuals but minimum qualifications, skills and experiences } \\
\text { are not prescribed. However trustees are expected to develop a policy in relation to fitness and } \\
\text { propriety in which they outline how they meet the fitness and propriety standard on an ongoing } \\
\text { basis including minimum requirements of new individuals and ongoing training requirements. }\end{array}$ \\
\hline Austria & $\begin{array}{l}\text { Members of the board of directors must not have any criminal record and criminal investigations } \\
\text { must not have been initiated. } \\
\text { Members of the board of directors of a single-employer pension fund are required to hold a } \\
\text { management position with the sponsoring employer. The directors of a multi-employer pension } \\
\text { fund must prove professional experience in the area of pension fund management, banking or } \\
\text { insurance and must have been in a management position for at least } 3 \text { years. }\end{array}$ \\
\hline Belgium & $\begin{array}{l}\text { At least two persons must be in charge of the management of a pension fund or life insurance } \\
\text { company and they must be professionally reliable and have adequate experience. } \\
\text { The members of the management board have to provide an overview of their professional expertise } \\
\text { and provide proof of their good repute. }\end{array}$ \\
\hline Brazil & $\begin{array}{l}\text { The members of the managing board, supervisory board, and audit committee must comply with } \\
\text { requirements concerning fitness and propriety. The members of the managing board must have } \\
\text { higher education. }\end{array}$ \\
\hline Denmark & $\begin{array}{l}\text { The DFSA may disqualify members of the board of directors of a pension fund or insurance } \\
\text { company if they lack sufficient experience or if they are not of good character. }\end{array}$ \\
\hline Finland & $\begin{array}{l}\text { The managing director and members of the board of directors of a pension insurance company } \\
\text { must be of good reputation and have good knowledge of the pension insurance business and of } \\
\text { asset management. They must not be legally incompetent, bankrupt or persons who have been } \\
\text { prohibited from undertaking business activities. }\end{array}$ \\
\hline Fran & $\begin{array}{l}\text { oncerning the governance of pension institutions or national associations } \\
\text { nd proper requirements for members of the board. }\end{array}$ \\
\hline
\end{tabular}




\begin{tabular}{|c|c|}
\hline Germany & $\begin{array}{l}\text { The persons in charge of the management of a life insurance company, Pensionkassen or } \\
\text { Pensionsfonds must fulfil certain requirements concerning fitness and propriety. } \\
\text { Fit and proper requirements for member of the managing board (Geschäftsleiter) are defined in } \\
\text { section 7a German Insurance Supervision Act (VAG). Members of the managing board must be } \\
\text { qualified or, in the words of the legislation, reliable and suited for the job. This is normally the } \\
\text { case when the managers have held a managing position within an insurance company or a pension } \\
\text { fund for at least three years and, if possible, knowledge of the portfolios for which they will be } \\
\text { responsible. A CV, a clearance certificate, an extract from the central trade register if previously } \\
\text { working independently and a negative pledge concerning criminal, misdemeanour, or insolvency } \\
\text { proceedings must be submitted, as well as information about relationships with supervisory board } \\
\text { members. }\end{array}$ \\
\hline Hungary & The members of the board of directors must have unblemished professional and civil records. \\
\hline Israel & All directors and officers of the company must have adequate qualifications. \\
\hline Iceland & $\begin{array}{l}\text { Members of a pension fund's board of directors must be competent to manage their own finances } \\
\text { and must not, during the previous } 5 \text { years, have been convicted of an offence connected with a } \\
\text { commercial activity punishable under the Criminal Code or Act on limited liability companies, } \\
\text { private limited liability companies, bookkeeping, annual accounts, bankruptcy or public levies. } \\
\text { Members of the board must be residents of Iceland or another member state of the European } \\
\text { Economic Area. These requirements also apply to the managing director. }\end{array}$ \\
\hline Italy & $\begin{array}{l}\text { At least one-half of the members of the governing board and the general manager must be of good } \\
\text { reputation (lack of criminal and insolvency antecedents) and fulfil certain professional } \\
\text { requirements. }\end{array}$ \\
\hline Japan & $\begin{array}{l}\text { There are no legal requirements concerning their internal governance structure or the fitness and } \\
\text { propriety of directors. }\end{array}$ \\
\hline Luxembourg & $\begin{array}{l}\text { Liability managers of SEPCAVs and ASSEPs must either be authorized by the Financial Sector } \\
\text { Supervision Commission (Commission de Surveillance du Secteur Financier - CSSF) on the basis } \\
\text { of criteria of competence, good repute and financial solidity, or by the Insurance Commission as a } \\
\text { life insurance company. } \\
\text { The pension fund must submit the curriculi vitae of the members of the supervisory bodies. There } \\
\text { are no defined legal criteria to assess the qualifications of the pension fund managers but, } \\
\text { according to the established administrative practice, such qualifications are deemed sufficient if the } \\
\text { pension fund managers possess a relevant university degree and have a certain number of years of } \\
\text { work experience. These criteria are applied by the CSSF on a case by case basis. }\end{array}$ \\
\hline Netherlands & $\begin{array}{l}\text { The De Nederlandsche Bank (DNB) may check the fitness and propriety of members of the } \\
\text { governing board and disqualify them. } \\
\text { The Guidelines for Pension Fund Governance include the following: } \\
\text { The governing body shall ensure that it meets all expertise requirements imposed by De } \\
\text { Nederlandsche Bank (DNB) on the basis of legislation and regulation. In addition, the governing } \\
\text { body shall lay down its own 'expertise plan', which stipulates the requirements for the body's } \\
\text { members. }\end{array}$ \\
\hline Poland & $\begin{array}{l}\text { Members of the management and supervisory board of the pension fund society must fulfill the } \\
\text { following requirements: } \\
\text { - Have full legal capacity; } \\
\text { - Have not been sentenced by a court for any offence against property, credibility of } \\
\text { documents, trade or the treasury; } \\
\text { - Have higher education; } \\
\text { At least two-thirds of the management board members must have a record of } \\
\text { employment of } 7 \text { years or more and at least one-third must have higher education in law } \\
\text { or in economics or be registered on the list of investment advisers; } \\
\text { No less than two Management Board members, including the President of the Management Board, }\end{array}$ \\
\hline
\end{tabular}




\begin{tabular}{|l|l|}
\hline & $\begin{array}{l}\text { shall have mastery over the Polish language. } \\
\text { At least one half of the supervisory board members must have higher education in law or } \\
\text { economics and at least one-half of the members must neither be shareholders of the pension fund } \\
\text { society nor sit on a governing or supervisory body of a shareholder of the pension fund society. }\end{array}$ \\
\hline Portugal & $\begin{array}{l}\text { Members of the board pension fund managing companies must meet requirements on professional } \\
\text { qualifications and experience. }\end{array}$ \\
\hline Spain & $\begin{array}{l}\text { There are no legal requirements concerning the fitness and propriety of members of control } \\
\text { commissions. Members of the board of directors of pension fund managing companies must meet } \\
\text { requirements on professional qualifications and experience. }\end{array}$ \\
\hline UK & $\begin{array}{l}\text { A person who has been convicted of an offence of dishonesty and deception, has been bankrupt, or } \\
\text { has been disqualified as a director of a company, may not be a trustee. }\end{array}$ \\
\hline USA & $\begin{array}{l}\text { There are no legal requirements concerning who may or may not be a trustee but conviction of } \\
\text { criminal acts and prior breaches of fiduciary duty may disqualify one from service as a fiduciary. }\end{array}$ \\
\hline
\end{tabular}

In general, Anglo-Saxon countries tend to apply few "fitness" criteria on trustees, though Australia has recently tightened these requirements significantly as part of the introduction of a new licensing regime overseen by the regulatory authority (APRA) over 2004-6. Since then, superannuation fund trustees (or responsible officers in the case of a corporate trustee) must explain and provide evidence that they satisfy the "fit and proper" requirement contained in the law. The "fitness" criteria must be met on a corporate or group basis and includes a working knowledge of the law and its application and basic investment knowledge. The "properness" criteria must be met by each individual (trustee or director of a corporate trustee) separately.

Together with the introduction of fund choice, the main effect of the new licensing regime in Australia has been to:

- Shrink the number of trustee entities (boards and corporations) in the system from over 1000 before July 2006 to under 300 by mid-2007

- Promote the role of independent, professional trustees and corporate trustees

- Consolidate the industry, with many small corporate pension funds being merged into the much larger industry funds and master trusts. 
Table 3. Superannuation entities in Australia

\begin{tabular}{|c|c|c|c|c|c|c|c|}
\hline & Jun 2001 & Jun 2002 & Jun 2003 & Jun 2004 & Jun 2005 & Jun 2006 & Jun 2007 \\
\hline \multicolumn{8}{|l|}{ By functional classification } \\
\hline Corporate & 3,224 & 2,434 & 1,862 & 1,405 & 962 & 555 & 289 \\
\hline Industry & 150 & 134 & 124 & 106 & 90 & 80 & 74 \\
\hline Public Sector & 81 & 76 & 58 & 42 & 43 & 45 & 40 \\
\hline Retail & 275 & 254 & 235 & 232 & 228 & 192 & 172 \\
\hline Small & 219,064 & 235,626 & 262,175 & 287,982 & 304,893 & 323,917 & 365,992 \\
\hline Pooled superannuation trusts & 177 & 179 & 160 & 143 & 130 & 123 & 101 \\
\hline Total & 222,971 & 238,753 & 264,614 & 289,910 & 306,346 & 324,912 & 366,668 \\
\hline
\end{tabular}

Source: APRA Superannuation bulletin (2007)

Figure 1. Superannuation assets in Australia, 1998-2007 (\$bn)

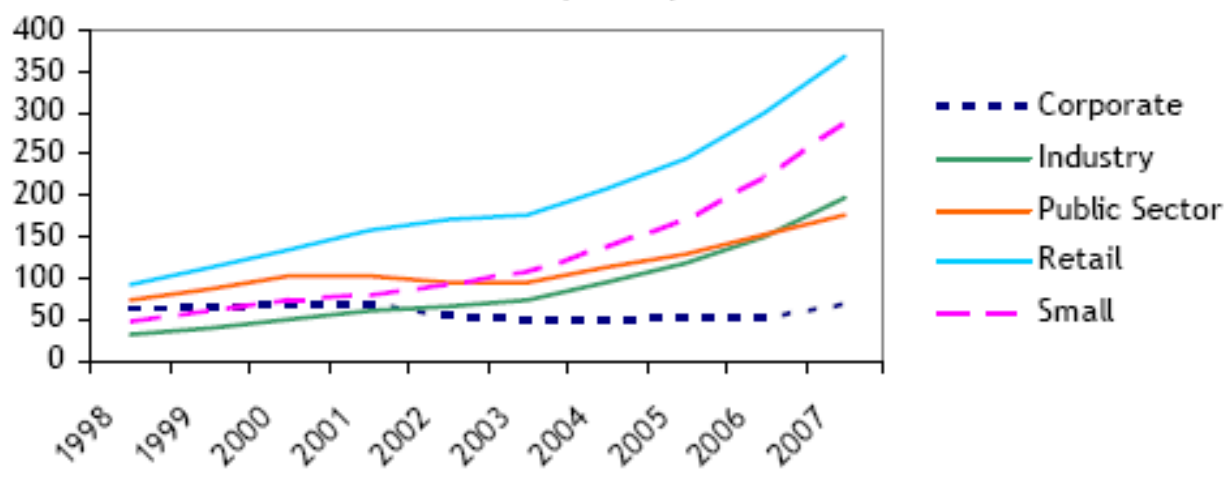

Source: APRA Superannuation bulletin (2007)

In contrast, in the United States, duties imposed by law on fiduciaries have been viewed as sufficiently rigorous to ensure, in most cases, that qualified individuals are appointed. Requirements of specific degrees or training are viewed as unnecessary because fiduciaries are usually drawn from the ranks of senior company management or are delegated experts and advisors.

In the United Kingdom, the 2004 Pensions Act required trustees to have the necessary knowledge and understanding of relevant legislation (including trust law), scheme rules, funding and investment matters. However, it does not assess these requirements via a licensing regime for trustees as is the case in Australia. Moreover, unlike in Australia, the "fitness" requirement is applied individually rather than on the board as a whole. The Pensions Regulator has introduced a framework for trustee knowledge and understanding (the TKU regime), promoting trustee training (see next section). 
The Act and TPR's initiatives have led to an increase in trustee training and greater separation of roles between trustees and the sponsoring company. As a result, some finance directors and other senior company executives have stepped down from boards of trustees. This in itself could have caused a major loss of expertise for the governing board, but this has been counterbalanced in some cases by the appointment of independent professional trustees. Independent trustees may be single individuals or trustee companies that appoint a specific staff member to the pension fund trustee board. Unlike employer and employee representatives, independent trustees are usually paid for their services.

Despite the growing importance of independent, professional trustees, the UK Pension Regulator's governance survey of trustees (TPR (2007b)) found that having a mixed boards (member and employer nominated) was regarded of much greater importance for good governance than having an independent trustee (see Table 4). One obstacle to wider use of independent trustees may be their cost, which may explain why it is mainly the larger pension funds that have appointed such trustees. However, a general apprehension to change by existing trustees could also be an explanatory factor and may explain why active encouragement of the professional trustee function by policymakers may be required. In Australia, for example, policymakers consider the presence of independent trustees to be in general a sign of good governance.

Table 4. Results from a UK survey of pension fund trustees over the main ways to improve governance

\begin{tabular}{|l|l|}
\hline \% strongly agree & Total \\
\hline Holding regular trustee board meetings & 74 \\
\hline Trustee training & 64 \\
\hline A mix of member-nominated and employer nominated trustees & 55 \\
\hline The level and experience of trustees & 54 \\
\hline Risk management procedures & 38 \\
\hline Regular, independent assessment of the performance of advisers and service providers & 35 \\
\hline Having a professional trustee on the board & 27 \\
\hline
\end{tabular}

Source: Pensions Regulator (2007b)

The following suggestions for improving the composition of pension fund boards are drawn from OECD guidelines and country experience:

- Encourage employee/ member nominated representatives, taking into account the need for an appropriate mix of skills and accountability to plan members.

- Define 'fit and proper' criteria more accurately, extending it to the collective knowledge and experience of the board and calling for suitable training where specific experience or knowledge are not required prior to appointment to the board.

- Consider the costs and benefits of introducing licensing for trustee entities (boards and corporations).

- Allow, and encourage, the use of independent professional trustees.

\section{V.4 Ensuring regular self-assessment and training}

One of the most difficult tasks of a governing board is to monitor its own performance. Selfassessment can help boards identify weaknesses in their monitoring and decision-making activities. In dual-board structures like Germany's, the management board is assessed by the supervisory board. In the case of single boards, the assessment of the board can be carried out by another internal body, such an 
audit or similar committee which may include external professionals. Such a body is to become a requirement in the Netherlands, as described in Box 2.

One potential problem with these oversight bodies is that they can lack sufficient strength or influence. One way to increase their powers may be to give them a 'whistleblowing' responsibility, with the requirement to report any governance or other problems they detect to the relevant pension supervisory authorities. 


\section{Box2. Internal supervision in Dutch pension funds}

The new Dutch governance standard requires pension schemes to set up internal supervision, allowing independent experts to evaluate the functioning of the pension fund and its management. Schemes can opt for internal supervision via a visitation commission (made up of at least two independent and experienced persons not already involved in the certificating of the fund's figures, looking at performance at least once every 3 years), or a permanent independent body within the pension fund itself which has at least 3 independent members. Other options are a one-tier board (OTB) or an audit commission designed to oversee the execution of pension fund management, which is made up of executives and a group of non-executive employers and employee representatives, as well as pensioners. In terms of structure, most funds opt for a visitation committee. A limited number of schemes have chosen a one-tier board, in which supervising board members check colleagues on implementation.

The new governance rules also require the establishment of an "accountability body", including representatives of participants, pensioners, and the sponsoring employer. Many pension funds have decided to have a single advisor and accountability body. PGGM, the second largest pension fund in the Netherlands, is an example of a fund which has reacted to the new governance environment. They have appointed 3 external members to their audit committee (made up of 7 in total, including 2 employer and 2 employee appointees), and they will also act as the internal supervisory committee, reporting on policy and governance procedures and processes as well as checks and balances at the pension fund every year.

According to a survey by the Dutch Central bank (DNB) as of mid $200790 \%$ of all pension funds had chosen to implement a visitation commission, though as of summer 2008 most had yet to start up the visitation process. According to the pension and governance rules, internal supervision should start from $1^{\text {st }}$ January 2008, with visitation commissions beginning their operations from 2008, 2009 or 2010. Starting operations late will have implications for the role of the accountability body as it will not be able to use the findings from its own internal supervision. A survey by KPMG Financial Services suggests that governance is still not a priority for Dutch pension funds, especially smaller funds, (which have been busy with the implementation of the new FTK, other reporting and legal requirements) and implementation challenges may have been underestimated. A survey by the OPF (Association of Company Pension Funds) found staffing of accountability and internal supervision bodies as the biggest hurdle. Some critics warn that these supervisory bodies will lack teeth and will not be able to counterbalance the management.

As a result of external assessments, the governing board may decide to pursue training or engage external independent experts to the board. Additional training is most likely required for boards where specific experience or knowledge requirements are not laid down by 'fit and proper' requirements (which is often the case in trust-based systems).

Some regulators are also providing indirect incentives for boards to pursue training. The UK Pension Regulator's governance survey (Pensions Regulator (2007b)) found that higher levels of trustee training continue to be associated with higher levels of governance activity and understanding of the board: "There is a clear relationship between the extent of training and those activities which we consider to represent good governance... The survey findings show that boards in which trustees have acquired knowledge and understanding about how schemes should be run are more likely to be able to govern their schemes well." The United Kingdom focus on educating trustees has led to the publishing of a code of practice, scope guidance (both produced after widespread consultation with the pensions industry), a syllabus and an elearning facility which is available to trustees at no charge, the Trustee Toolkit. ${ }^{15}$ The Pension Regulator's

\footnotetext{
${ }^{15}$ See http://www.trusteetoolkit.com/arena/index.cfm
} 
governance survey (Pensions Regulator (2007b)) has shown marked increases in trustee training which indicates the success of this strategy.

An example is given in their discussion paper, examining the survey results (Pensions Regulator (2007a)) "As an example, we can take the trustee who has always accepted performance benchmarks as a given but who has learnt for the first time how they are put together and the importance of the appropriateness of the benchmark for a scheme. Thereafter the trustee is much more likely to examine performance benchmarks carefully." Trustee boards which had undertaken training (and meet more frequently) were more likely to have reviewed the sponsoring employer's covenant and employer's credit rating. They were also more confident in their ability to make such assessments (which was also boosted if they took external advice). In addition, those who undertook training were more likely to identify conflicts of interest and have policies in place to deal with them. Those which have had training (and meet more frequently) are more likely to review the scheme's investment strategy.

The Pensions Board in Ireland concluded its trustee report (Pension Board (2006)) with mixed views regarding compulsory training. Their recommendation is to make training compulsory (within 6 months of appointment and then every 2 years), ${ }^{16}$ but with the Pensions Board taking on much of the responsibility for providing this education (free to avoid burden on schemes) - suggesting an approach similar to the UK Pension Regulator's on-line training resource. The Board also provides a list of approved training programmes and recommends all trustees should attend training together as far as practicable. There is also the requirement that every scheme have a copy of the Trustee Handbook. The report does acknowledge that in the absence of mandatory training some extension of trustee requirements to ensure increased knowledge and ability may be required.

The International Organisation of Pension Supervisors recently produced a working paper looking at education and training provided by pension supervisory authorities (IOPS (2007)). Though examining the provision of education to various stakeholders (and identifying a positive impact on all groups trained), the report highlights trustees as the most significant target group, due to the key role they play in the management of schemes and their expressed desire for greater knowledge and training. Yet the report finds that the training of trustees is inadequate, firstly as it is not compulsory and as it is usually only provided on a one-off basis (with follow up training often proving prohibitively expensive). The report therefore encourages pension supervisors to fill the gap with affordable, accessible education opportunities, with surveys finding that trustees may prefer the supervisor to be the source of education. The costs to the supervisory authority can be reduced, for example via on-line training, imposing fit and proper requirements, certifying training courses, etc. The Kenyan supervisory authority (the Retirement Benefit Authority), for example, carries out research to identify needs and target their education resources effectively (also attending AGMs to answer questions and providing training to employers). The costs should be offset with better governance reducing overall regulatory and supervisory requirements (such as in-depth investigations).

International good practice suggests assessment and training may be improved in the following ways, which could be particularly beneficial to trust-based systems:

- Encourage self-assessment by boards

- Allow third-party monitoring and give such oversight bodies 'whistleblowing' powers

- Provide guidance on level and types of knowledge required by governing board members

162003 Pension Board Ireland research found $75 \%$ trustee undertook a training course within 12 months of appointment. $65 \%$ did not receive any additional or specialist training and $71 \%$ did not receive a refresher course. 
- Encourage training of board members - not just on appointment but on a regular, on-going basis

- Provide free training (e.g. on-line)

- Advise board members where training can be obtained

- Approve training courses

- Allow pension fund to pay for training of board members.

- Encourage the use of experts to provide technical support (though stressing that board members should not rely on one source, and should have the knowledge to assess such advice adequately).

\section{V.5 Handling conflicts of interest}

Conflicts may arise whenever the decisions of a board member concerning the pension fund are, or may be perceived to be, affected by a separate personal interest or a duty owed to another party, rather than that of the pension fund members and beneficiaries. Employer representatives are generally affected by conflicts whenever decisions have to be taken that affect the sponsoring employer. Employee representatives can also be affected by conflicts. For instance, they may place greater value on the wellbeing of members of similar age and gender as their own.

There may be a variety of ways to manage conflicts of interest, including use of a number of measures, or a combination of approaches - for example through the appointment of independent board members, establishing an executive sub-committee or board members withdrawing from a meeting. Some regulators (such as TPR in the United Kingdom, APRA in Australia) have the ultimate ability to work with or replace conflicted trustees, with similar powers recently being requested by the Financial Services Board in South Africa (avoiding length court cases which were previously required in such circumstances) ${ }^{17}$. In cases of an acute conflict it may even be appropriate for a trustee to resign.

The management by trustees of conflicts of interest is integral to good scheme governance. Trustee boards should ensure that they have in place effective processes for identifying, monitoring and managing conflicts. The Pensions Regulator in the United Kingdom considers the formalization of a conflicts policy at scheme level to be a very important part of conflicts management, though a large number of schemes have yet to implement this (a gap recognized by the TPR which therefore plans to issue specific guidance). The management of conflicts of interest may also be helped by having a mixed board, possibly with independent trustees. For example, the UK Pension Regulator's governance survey (Pensions Regulator (2007b)) found that the majority of UK schemes replied that having member nominated trustees and professional trustees on the board improves governance. There seem to be two ways to achieve this result:

- Impose legal requirements for certain representation on boards, with supervisory oversight then checking representation is real and that board is acting in interests of members (if not the supervisor should have the right to change the composition of the board or appoint independent trustees - see Table 1 on member-nominated board requirements).

- Encourage such mixed representation, for example providing templates for ideal boards and explaining their advantages

\footnotetext{
${ }^{17}$ The UK regulatory recently used these powers in relation to the Telent Pension Scheme. Details of the regulator's decision can be found on: http://www.thepensionsregulator.gov.uk/pdf/GEC1972.pdf
} 
One argument in support of non-sponsor appointed trustees is that they provide an independent check that fiduciary duties are being met, which could avoid potential law suits from members, or problems with the regulator (and risk an independent trustee being forced upon the board by regulatory authorities).

The Irish Pension Board's report (2006) found that most boards "do not consist predominantly of amateurs, but a mix of professional skills and other attributes, purposely chosen by employers and members to bring such skills to the trustee tables. Professional trustees are also regular participants on trustee boards, bringing an experience in trustee practice that was deemed particularly valuable by those trustees interviewed on whose boards they sit." Key decisions which require voting were rare. Employer nominated trustees often drive the decision making (doing research on topics etc.) - but member nominated ones did not see this as a particularly problematic. One criticism was that some member nominated trustees could not separate role of worker representative and trustee (e.g. bringing up discussion of compensation levels etc. at the board meetings).

The Irish Pension Board's report (2006) also examines the specific case where the employer acts as sole trustee, which clearly involves an added risk of conflicts (often as sponsors are not aware of their duties as a trustee) - especially regarding payment of contributions. Where the employer is the only trustee and the sponsoring firm is in liquidation, insolvency practitioners or regulators often have discretion to appoint an independent trustee (though discretion should be exercised as this imposes costs on the funds which may be in financial difficulties already). For this purpose, regulators may keep a register of potential trustees.

The United States has a broad set of regulations aiming at controlling conflicts of interest, including so-called prohibited transactions that any plan fiduciary may not enter into (directly or indirectly). Those include for example, sales or exchanges, leases, and loans between the plan and a person or entity that is a "party in interest" to the plan's fiduciary. The Department of Labor may exempt a specific transaction from the prohibited transactions restrictions. The US approach to managing conflicts in pension funds is largely a result of its governance structure that allows a relatively high degree of control of multiemployer funds by a joint board and of other pension funds by plan sponsors.

In addition to addressing potential conflicts of interest stemming from the relation between governing board members and their constituencies (employers or employees), regulations must consider the potential for self-dealing by board members and the fund's operational staff. Self-dealing transactions occur when a party makes decisions that cause unjust enrichment directly or indirectly. Conflicts of interest regulations must prohibit governing board members from engaging in self-dealing and must require them also to address potential conflicts of interest among their internal staff. Conflicts of interest rules may be included in a code of conduct that all board members and operational staff must abide to.

Self-dealing is the main form of conflicts of interest regulations addressed in countries where pension funds do not take the trust form. In Germany, for example, during their employment for the pension entity, members of Management Boards are subject to a comprehensive non-competition obligation. Members of the Management Board and employees may not, in connection with their work, demand, accept or grant payments or other advantages to or from third parties. Members of the Management Board are bound by the pension entity's best interest and:

- may not pursue personal interests in his decisions or use business opportunities intended for the enterprise for himself;

- must disclose conflicts of interest to the Supervisory Board without delay and inform the other members of the Management Board; 
- may only take on sideline activities -especially Supervisory Board mandates outside the enterprise - only with the approval of the Supervisory Board;

- must ensure that any transactions with the enterprise comply with standards customary in the sector, with important transactions requiring Supervisory Board approval.

All members of the Supervisory Board are also bound by the enterprise's best interests. In addition, members of the Supervisory Board:

- may not pursue personal interests in his/her decisions or use business opportunities intended for the enterprise for himself/herself;

- must inform the Supervisory Board of any conflicts of interest which may result from a consultant or directorship function with clients, suppliers, lenders or other business partners.

- $\quad$ must - in the report of the Board - inform the General Meeting of any conflicts of interest which have occurred together with their treatment. Material conflicts of interest and those which are not merely temporary result in the termination of the Board member's mandate.

- $\quad$ require the Supervisory Board's approval for advisory and other service agreements and contracts for work and the company.

The following examples drawn from international good practice, are suggestions for overcoming governance shortcomings stemming from conflicts of interest:

- Require a policy - such as a code of conduct - for identifying potential conflicts of interest and for dealing with them when they arise and require board members to notify compliance on an annual basis. Potential conflicts should be disclosed and noted in the minutes of board meetings;

- Conflicted board members should abstain from voting on issues involving them (and should resign as a last resort);

- Authorities should have the ability to remove members from boards or to appoint an independent board member if conflicts persist and cannot be solved;

- An independent board member should be appointed in a situation where the employer is the sole trustee and is in liquidation;

- Templates for ideal boards could be produced (type of representation, skills required etc.);

- Provide that transactions between the pension fund and related parties which may be prone to such conflicts be per se prohibited unless approved by the supervisory authority by class or individual exemption, as in the United States.

\section{Addressing governance deficits in contract-based, defined contribution plans and personal pension arrangements}

Defined contribution (DC) plans present additional governance challenges arising from the involvement of individual members in some key decisions. In most DC plans, members face investment choices which they may not be well prepared to make. Conflicting interests are at the heart of many of the complaints often heard about defined contribution plans, from high fees to unsuitable investments and poor 
performance. While improving members' financial education and enhancing disclosure can help overcome some of the more blatant cases of abuse, it is highly unlikely to eliminate the massive information gap between private pension providers and individual plan members ${ }^{18}$.

This information gap is aggravated by the fact that contract-based DC plans and personal pension arrangements are not usually run by a governing board that caters exclusively to the interest of members and beneficiaries. Under occupational, contract-based DC arrangements, employers negotiate to set up a pension plan directly with pension providers, without any intervention of trustees or equivalent bodies. When the employee joins, a direct contractual relationship is established between individual members and private pension providers, and employers normally have no direct contractual relationship with the provider. Often there is no collective body representing members' interests which oversees the appointment of the pension provider or engages in on-going monitoring of services provided. In such cases, the governing body of the pension fund is the same as that of the private pension provider.

Though the pension provider has a fiduciary duty to manage the pension interests on behalf of pension fund members, concerns have been raised in some countries that conflicts of interest intervene. Some conflicts of interest, such as self-dealing over investments or cross-selling of different products to plan members, can be addressed via suitable regulations. For example, pension fund managing companies in countries such as Mexico, Poland, Portugal and the Slovak Republic, are subject to restrictions on investments in entities related to the pension provider. On the other hand, the choice of investments and the assessment of their different cost and performance are left to individual plan members in the expectation that market forces will lead to efficient outcomes. Given the complexity of investment matters and the long horizon of pension matters, such expectations may seem unwarranted.

Given the growing importance of contract-based, DC pensions and personal pension arrangements, finding a solution to the additional challenges of DC governance (sometimes referred to as the "governance vacuum") is an imperative task for employers and policymakers, especially in those countries where DC pension funds are mandatory. Potential solutions which can be proposed to address this challenge include:

- Establishing an independent management committee or similar governance body (e.g. union, employee representatives, staff forum) whose function is to review how the contract-based scheme is working (e.g. looking at administration, investment choices, member communications etc.).

- Creating the legal environment for employers to become also monitors of DC pensions and playing a role in guiding individual members' choices (e.g. encouraging financial education, limiting the number of choices available and only allowing certain types of funds to be offered as defaults). In personal pension arrangements, the equivalent policy would be to increase the fiduciary responsibilities of private pension providers.

- Strengthening the role of pension fund supervisory authority in monitoring private pension providers.

\footnotetext{
${ }^{18}$ In its consultation document 'the governance of work-based pension schemes' (Pensions Regulator (2007a)), the UK's Pensions Regulator identified a number of potential conflicts that could arise under trust-based schemes and suggested ways to manage them. Its work also suggested that the kinds of conflicts of interest associated with trust-based schemes do not arise under contract-based schemes (paragraph 12.15).
} 


\section{VI.1 DC management committees}

In contract-based occupational DC plans, an independent DC management committee may carry out many of the monitoring functions which internal governing boards perform in pension funds of the institutional type and which trustees carry out in trust-based schemes. However, such committees often do not have any decision-making power. Recent research by TPR in the United Kingdom found that approximately half employers with group personal pensions had a governance arrangement involving such committees. Such arrangements are also allowed in Japan but are not common.

In its consultation document 'the governance of work-based pension schemes' (Pensions Regulator (2007a)) the UK's Pensions Regulator explained that the employer has no formally defined role in the ongoing administration and review of contract-based schemes ${ }^{19}$, though the employer will usually have selected the scheme and will have the ability to change it which can give some influence over the provider (see paragraph 12.10). TPR also suggested that one way of voluntary employer engagement in contractbased schemes might be through employer-led management committees (see paragraph 12.40). Examples of how a management committee might be involved in areas such as monitoring the investment performance of the fund, the quality of service provided to members and ensuring members are provided with timely and useful information were published. TPR also issued guidance on voluntary employer engagement in work-place, contract-based pension schemes, which suggest ways for employers to take a greater interest in their contract-based DC schemes (e.g. management committees, via their advisor and other groups, such as unions or staff forums, etc.).

Another interesting case is Australia, where "policy committees" can be established under so-called public offer funds (those that any employee can join) for plan sponsors with 50 or more plan members. The functions of a policy committee are to provide an avenue for members to enquire about the investment strategy, operation and performance of the fund, for the trustee to obtain the views of members on the strategy, operation and performance of the fund and the information needs of members, and to assist the trustee in dealing with complaints or inquiries about the operation or management of the fund. There is some anecdotal evidence that such committees have not been very effective.

In Portugal management committees are set up on a mandatory basis for occupational pension schemes - for all types of pension plan, not only DC plans - that cover more than 100 members and/or beneficiaries according to the new legislation and regulation passed in 2006 and 2007. The protection of individual pension arrangements is also considered in the Portuguese legal framework through the implementation of a pension ombudsman, which has consultative powers and is responsible for appraising complaints presented by members and beneficiaries of pension funds.

One example of a management committee with greater decision-making powers than those in Australia or the United Kingdom is the so-called "control commission" introduced in Spain for both occupational and personal pension plans in 1987 and which still remains in place for the former. The role of this commission in occupational plans was strengthened by regulatory changes in 2004, giving it more responsibilities of a typical governing body.

While DC committees can be effectively established in occupational contract-based plans, they may not be suitable for personal pension arrangements. There is first of all the question of how to select representatives of plan members to the committee. Unlike in occupational plans where representatives of employers and employees are usually appointed to the governing body, in a personal pension arrangement

\footnotetext{
${ }^{19}$ The Pension Regulator's definition of “contract-based, workplace DC schemes” includes so-called "group personal pension schemes" and "stakeholder pensions" which are classified as occupational plans under the OECD taxonomy.
} 
membership can be highly disperse and there may be no well known candidates for the committee. Secondly, there is the question of the legal nature of the committee. These difficulties may explain why in none of the Central and Eastern European and Latin American countries that have introduced contractbased, DC pension plans over the last decade are there DC management committees with member representatives.

These difficulties also led to the introduction of a law in Spain in 2001 that eliminated the control commission of personal pension plans. It was felt that the commissions were ineffective in achieving their stated goals - the plans and funds were ultimately controlled by the financial institutions responsible for them - and that there was a general lack of interest by members in electing candidates. Instead, a pensions ombudsman was established, whose role is to attend to complaints by members and beneficiaries and seek remedial action.

In contrast, in Italy recent reforms in relation to DC open pension funds (those which have open membership) have addressed the governance issue by requiring them to establish a Supervisory Board ('Organismo di Sorveglinanza'). The role of the Board, whose members must respect independence requirements established by law, is to oversee that the pension fund is operated in the sole interest of members. The Board also has a whistleblowing role to the supervisory authority. When at least 500 members belong to the same firm/ group, the law requires that members of the Board are also appointed by workers and the firm/ group. In addition a Fund Director ('Resonsabile del fondo') now has to be appointed for all types of pension funds and plans. Their role is to verify that the fund is managed according to the interests of members and beneficiaries and in compliance with respect to legal and statutory provisions (investment rules, conflict of interest rules etc.). They also provide the necessary information to the Supervisory Board. Independence requirements for the appointment of the Fund Director are established by law for open pension plans and individual plans realized through life insurance policies offered by and managed by financial institutions (it should be noted that the Fund Director is not part of the Board of Directors of the financial institution which manages the fund).

To conclude, there seems to be a strong case for management or advisory committees in contractbased occupational DC plans, carrying out some of the oversight functions that would be performed by trustees or equivalent governing bodies and promoting the 'collective interest' of members of such DC plans. One option to improve the functioning of such management or oversight committees may be to give these bodies 'whistleblowing' responsibilities, with the requirement to report any governance or other problems to the relevant supervisory authority. On the other hand, there are major difficulties to establishing and ensuring the operational effectiveness of such committees in personal pension plans.

\section{VI.2 Enhancing the fiduciary responsibilities of employers and providers}

Additional fiduciary responsibilities could be imposed on employers and providers to promote the protection of the interest of contract-based DC plan members and beneficiaries. Additionally, in occupational plans, legislation can clarify the role of employers in providing advice and education to plan members, facilitating the investment choices made and promoting more successful outcomes.

One of the main recommendations from the Cass report (Byrne et al (2007)) for the United Kingdom is that in exchange for a greater fiduciary role, employers, trustees, advisors and other involved parties should be protected through the introduction of safe harbour rules. The report claimed that current UK regulations can actually be counterproductive, with perceptions of legal liability meaning that members are 'left to their own devices', with employers reluctant to provide advice and the vast majority of individuals remaining in sub-optimal default funds. However, the measures currently being put into place by the UK's Pensions Regulator can be accommodated within the current legal and regulatory framework and are designed to result in changes in behavior that lead to improvements in the areas where the regulator's 
consultation work has identified scope for improvement. The UK Pension Regulator's consultation paper on how it intends to regulate DC pensions (Pensions Regulator (2007a)), highlights areas where it has identified opportunities for improvements, and the Regulator has stated that it will issue guidance with the aim of raising standards in those areas (with the emphasis on clarifying the role of employers in educating and informing members, and tackling the issue via a system of voluntary compliance and codes of practice).

"Safe harbour" rules have been effectively implemented in the United States. Fiduciary responsibility for fund performance is only waived in DC plans when employers offer at least three investment choices with different risk-return combinations. The 2006 Pension Protection Act and related Department of Labor rulings added another layer of safe harbor regulations by identifying qualified default options that would allow employers to enroll employees automatically into DC plans without triggering a fiduciary liability for bad performance for those who did not make an active investment choice. The United States occupational DC system contrasts with the Australian one, as there are no requirements over investment choices or default options. Most pension funds offer a wide range of investment choices and sometimes such choice can be overwhelming. Formally, trustees are only required to offer options that are effectively well diversified and to inform members of the choices and risks they face.

In some countries with contract-based DC systems, like Italy (open pension funds), Portugal and Spain, there are also few fiduciary requirements on employers or providers regarding investment choices, default options and financial education. On the other hand, in Japan, which introduced occupational, contract-based DC plans in 2001 has laid out a set of strict fiduciary obligations on employers. The law requires sponsoring employers to exert their best efforts to select investment options prudently, disseminate information and educate employees regarding investment issues in order to improve their financial literacy. However, this requirement does not extend to a fiduciary responsibility over investment performance.

A similar policy approach can also be implemented in personal pension arrangements. For example, in Turkey, pension fund providers are required to assess the risk-return preferences of each of their members prior to recommending any specific investment choice.

\section{VI.3 Strengthening the governance role of the pension fund supervisory authority}

In countries where the pension fund system is highly concentrated (as tends to be the case in many mandatory personal pension systems) it is possible for the supervisory authority to play a role in regularly monitoring the investment and other decisions taken by private pension providers. For example, in Mexico, there is a daily feed of information from the twenty pension fund managers to the supervisory authority, CONSAR, which allows the latter to identify any instance of breach of investment regulations. Moreover, the range of investment choices (five currently) is set in by regulation as are the default options, facilitating investment selection by plan members. CONSAR is also in charge of assigning new employees who do not make a choice of private pension provider to the ones giving the highest net return.

Yet, while investments are highly regulated and regularly monitored the same cannot be said of the fees charged by the pension fund managers. In the past, providers were allowed to charge different kinds of fees, which made comparing across providers extremely difficult for plan members. Since 2007, however, only one type of fee is permitted, on assets, which has enhanced transparency (including over investment performance) and is expected to encourage competition in the market.

In effect, the Mexican case represents a case of the "policymaker as trustee", as all the key decisions regarding investment options and defaults, and ongoing performance monitoring are in the hands of the pension fund supervisor. Similar regulations are in place in Hungary, Poland, and the Slovak Republic. 
Such mandatory individual account systems lend themselves to such a governance structure. On the other hand, it does not seem applicable to occupational DC pension systems where there is a multitude of pension funds.

- Suggested solutions, drawn from international good practice, to the challenges arising from the governance of contract-based DC plans include the following: Improve disclosure and communication to members (e.g. provide comparative performance and fee tables, personal pension statements, with estimated retirement income, comparison of asset allocation vs. peers etc.)

- Encourage collective governance structures to be put in place for contract-based DC schemes and give such oversight bodies 'whistleblowing' powers

- Encourage governing boards to ensure that individual choices and default options are structured properly

- Where members take on risk, provisions should be made for their input into appointments and other decisions (either via representation on the governing body or at least via an approval process at the AGM)

- Ensure there is on-going monitoring of investment options and providers - either the plan sponsors (via the creation of an appropriate legal environment), or potentially via an independent management committee

- Create the appropriate legal environment ('safe harbor rules') to allow sponsoring employers pension providers to fulfill fiduciary duties

- Strengthening the role of pension fund supervisory authority in monitoring private pension providers.

\section{Concluding remarks}

Improving governance remains a challenging task for pension funds and their regulators around the world. While recent regulatory and industry initiatives have improved the situation, there are still many cases of underperformance driven by bad governance practices. Some of the more serious cases of governance failures could be solved through a more balanced representation of stakeholders in the governing body, higher levels of expertise - which may be achieved via training as well greater use of independent, professional trustees (particularly where 'fit and proper standards do not require specific knowledge and experience) - and the design and implementation of a code of conduct that effectively tackles conflicts of interest.

Contract-based DC pension plans also present a major governance challenge in many countries that needs to be addressed urgently. These concerns emerge largely from the absence in such arrangements of a trustee or an equivalent governing body that represents exclusively the interest of plan members. There is potentially a role for employers and employee representatives in reviewing how contract-based schemes are working in practice via establishing DC management committees. The fiduciary responsibilities of sponsoring employers (in occupational plans) and providers (in personal plans) could also be clarified in order to ensure that the plans are managed with appropriate care and with the interest of the members in mind. In countries with highly concentrated pension fund markets, the pension fund supervisory authority can also play a central role in monitoring pension fund governance. 
In addition to solving these governance challenges, regulators and industry associations should also work together to promote pension funds that are large enough in size to facilitate their governance. Smaller pension funds have a governance handicap, as they tend to have higher management costs and more limited access to good trustees than larger funds and may also have insufficient scale to establish fully developed governance structures. For many countries, the consolidation of the pension fund industry is therefore a critical step to improve pension fund governance, bearing in mind potential legal and logistical issues. In this regard, policymakers may consider studying the Australian experience in licensing trustees, which has accelerated the growth of membership and assets in not-for-profit industry-wide pension funds and retail (or open) funds, leading to a rapid consolidation of the industry in the largest players. 


\section{REFERENCES}

Ambachtsheer K., Capelle R., Lum H., (2006), 'Pension Fund Governance Today: Strengths, Weaknesses, and Opportunities for Improvement', Financial Analysts Journal, October 2006

http://www.rotman.utoronto.ca/icpm/2.pdf

Ambachtsheer K., Capelle R., Lum H., (2007), 'The State of Global Pension Fund Governance Today: Board Competency Still a Problem', Rotman International Centre for Pension Management'

http://www.rotman.utoronto.ca/userfiles/departments/icpm/File/October\%202006/Governance\%20Study\% 20Paper Submission June\%202007.pdf

Bikker, J., de Dreu,J.,(2006) 'Pension Fund Efficiency: the Impact of Scale, Governance and Plan Design', DNB Working Paper No.109, August 2006

http://www.dnb.nl/dnb/home/file/Working\%20Paper\%20No.\%20109-2006 tcm47-146766.pdf

Byrne A., Harrison D., Blake, D. (2007) 'Dealing with the Reluctant Investor', Cass Business School

http://www.pensions-institute.org/reports/PI_DC_Investment_Final.pdf

Clapman, P. et al. (2007) 'Committee on Fund Governance: Best Practice Principles', Stanford Institutional Investors Forum,

http://www.law.stanford.edu/program/executive/programs/Clapman_Report-070316v6-Color.pdf

Clark, G.L., (2007) 'The Growing Tension between Expertise and Representation: UK Legislation on Pension Fund Governance and US Regulation of the Mutual Fund Industry', $21^{\text {st }}$ Century Society Journal of the Academy of Sciences 2:1-23

Clark G.L., Caerlewy-Smith E., Marshall J.C., (2007), 'The Consistency of UK Pension Fund Trustee Decision Making', Journal of Pension Economics and Finance, Volume 6, Issue 1, March 2007

Clark G.L., Caerlewy-Smith E., Marshall J.C., (2006), 'Pension Fund Trustee Competence: Decision Making in Problems Relevant to Investment Practice', Journal of Pension Economics and Finance, Volume 5, Issue 1, March 2006

Clark, G.L. and Urwin, R. (2007), 'Best-Practice Investment Management: Lessons for Asset Owners from the Oxford-Watson Wyatt Project on Governance'

http://www.geog.ox.ac.uk/research/transformations/wpapers/wpg07-10.pdf 
Cocco.J.F, Volpin, P., (2005), 'The Corporate Governance of Defined Benefit Pension Plans: Evidence from the United Kingdom', Centre for Economic Policy Research

http://www.cepr.org/pubs/new-dps/dplist.asp?dpno=4932

Dias, L. (2006), “Governance of Brazilian Pension Funds", working paper hosted by The Berkeley Electronic Press.

http://law.bepress.com/cgi/viewcontent.cgi?article=6568\&context=expresso

IOPS, (2007), 'Supervisory Education, Outreach and Communication, Including Training of Trustees', Working Paper No.2, 2007 - www.iopsweb.org

IOPS (2008), “The Supervisory Oversight of Pension Fund Governance paper, forthcoming IOPS Working Paper.

Lewin C., Sweeney E., (2007) 'Deregulatory Review of Private Pensions: a Consultation Paper', UK Department of Work and Pensions

http://www.dwp.gov.uk/pensionsreform/pdfs/consultation_paper.pdf

Marr, B., Blackwell, J., Donaldson K., (2006) 'Restoring Confidence: Measuring and Managing Performance in Pensions, Crafield University School of Management, Higham Dunnett Shaw

http://www.highamgroup.com/press/Measuring\%20and\%20Managing\%20Performance\%20in\%20Pension $\underline{\text { s.pdf }}$

Marossy, A. and Yermo, J. (2001), "Pension Fund Governance", Insurance and Private Pension Compendium for Emerging Economies, Book 2, Part 1:4)b, OECD.

http://www.oecd.org/dataoecd/6/56/1815934.pdf

Mercer Human Resource Consulting, (2006) 'Global Governance of Retirement Plans Survey 2006: Meeting the Challenge of Implementation: Europe'

http://www1.mercerhr.com/governancesurvey?contentId=1251380\&profileId=\&profileChecksum=null\&d ynamoSessionID=Z3AR1APHP5VP0CTGOUFCHPQKMZ0QUJLW\&geographyId=-1\&topicId=$\underline{1 \& \text { topicId }=-1 \& \text { localeCountry=en_US\&localeLanguage }=\text { en }}$

National Association of Pension Funds UK (2005), 'Fit for the 21 ${ }^{\text {st }}$ Century', Discussion Paper, July 2005.

National Association of Pension Funds UK (2007a), 'Institutional Investment in the UK 6 Years On', http://www.napf.co.uk/DocumentArchive/Policy/Reports\%20and\%20Responses \%20to\%20Consulta tions/10_2007/20070122_Institutional\%20Investment\%20in\%20the\%20UK\%20Six\%20Years\%20O n\%20-\%2022\%20Jan\%202007.pdf

National Association of Pension Funds UK (2007b), 'Annual Survey 2006'

OECD (2005), Guidelines for Pension Fund Governance: Recommendation of the Council.

http://www.oecd.org/dataoecd/18/52/34799965.pdf 
OECD (2006), Guidelines on Pension Fund Asset Management: Recommendation of the Council. http://www.oecd.org/dataoecd/59/53/36316399.pdf

Pensions Board, Ireland, (2006) 'Report of the Pensions Board to the Minister for Social and Family Affairs on Trusteeship', Pensions Board

http://www.pensionsboard.ie/index.asp?locID=62\&docID=39

Pensions Regulator, UK, (2007a) 'The Governance of Work-based Pension Schemes' http://www.thepensionsregulator.gov.uk/pdf/discussionPaperGovernance.pdf

Pensions Regulator, UK, (2007b) 'Occupational pension scheme governance : a report on the 2007 scheme governance survey'

http://www.thepensionsregulator.gov.uk/pdf/finalGovernanceSurveyJuly2007.pdf

Pensions Regulator, UK, (2007c) 'How the Pensions Regulator will Regulate Defined Contribution Schemes in Relation to Risks to Members'

http://www.tpr.gov.uk/pdf/conReportDefinedContribution.pdf

Pew Centre on the States (2007), 'Promises with a Price: Public Sector Retirement Benefits'.

http://www.pewtrusts.org/uploadedFiles/wwwpewtrustsorg/Reports/State_policy/pension_report.pdf

Rusconi, R. (2008), South African Institutional Investments: Whose Money is it Anyway?, mimeo, January 2008.

Stewart, F. (2005), "Developments in Private Pension Schemes Governance", OECD Working Party on Private Pensions discussion paper.

Thornton P., (2007) ‘A Review of Pensions Institutions', Department of Work and Pensions

http://www.dwp.gov.uk/pensionsreform/pdfs/InstitutionalReviewFinalreport180507.pdf 